\title{
Caring for older people with dementia in the emergency department.
}

WATKINS, S., MURPHY, F., KENNEDY, C., GRAHAM, M. and DEWAR, B. 


\section{The experiences of giving and receiving care for an older person with dementia in the Emergency Department (ED): An integrative literature review.}

Short title: Caring for older people with dementia in ED

Sarah Watkins, Candidate Advanced Nurse Practitioner (Acute Medicine), PhD candidate $^{1}$

Fiona Murphy, Professor of Clinical Nursing ${ }^{2}$

Catriona Kennedy, Professor of Community Nursing ${ }^{3}$

Margaret Graham, Lecturer ${ }^{4}$

Belinda Dewar, Professor of Practice Improvement ${ }^{5}$

Emergency Department, University Hospital Limerick, Ireland ${ }^{1}$

Department of Nursing and Midwifery, University of Limerick, Ireland²

School of Nursing and Midwifery, Robert Gordon University, Aberdeen, Scotland ${ }^{3}$

Department of Nursing and Midwifery, University of Limerick, Ireland ${ }^{4}$

School of Health and Life Sciences, UWS Lanarkshire Campus, South Lanarkshire, Scotland ${ }^{5}$

Corresponding author: Sarah Watkins, sarah.watkins@ul.ie, 0879313687 


\section{Abstract}

Background: Admission to an emergency department (ED) may expose the older person with dementia to a range of negative consequences, including a deterioration in their behavioural symptoms. The authors conducted a review of primary research relating to the experiences of older people with dementia, their carers and ED nurses, to understand how these experiences might inform nursing practice.

Methods: Integrative review with a search of the electronic databases of Medline, CINAHL and PSYCHINFO using specified inclusion and exclusion criteria.

Results: Three themes were identified: carers and older people with dementia-waiting and worrying; nurses juggling priorities; and strategies for improvement-taking a partnership approach.

Conclusion: Older people with dementia may be exposed to disparities in treatment in the ED. A practice partnership between carers and ED nurses may help to prevent this. ED nurses need support to blend technical- and relationship-centred care. Participatory research exploring the experiences of older people with dementia, their carers and ED nurses is needed.

\section{Keywords:}

Experiences, dementia care, emergency care, carers, nurses, relationship centred

\section{Key points}

- The focus of ED is to address acute care needs; however the older person with dementia may have other needs which are less well addressed in this setting.

- For nurses in ED, there may be a tension between providing technical, safety orientated care and more relationship centred care.

- Strategies are needed to support ED nurses to blend relational and technical aspects of nursing care to improve the experience of the person with dementia and their carers in an ED setting.

\section{Reflective questions}

Think of an episode or caring for an older person with dementia in your practice.

- Consider the relational care you have provided for older people living with dementia.

- Reflecting on this experience, how might you blend technical and relational aspects of care towards improving your practice?

- What would you do differently next time round? 


\subsection{Introduction}

Internationally it is estimated that 21 to $42 \%$ of older people attending an Emergency Department (ED) will have cognitive impairment or dementia (Gagnon-Roy et al, 2018). The World Health Organisation (WHO) identifies dementia as a global public health challenge (Wortmann 2012). It is predicted that the incidence and prevalence of dementia will rise to 131.5 million people worldwide by the year 2050 (Digby et al. 2018).

Dementia is an umbrella term used to describe a progressive decline in cognition. Symptoms are devastating, affecting the person's ability to fully and equitably engage in everyday activities (Alzheimers Disease International 2019). Older people are mostly affected and in the advanced stages of dementia frequently require hospital admission for complications related to urinary tract and respiratory tract infections (Pinkert et al. 2018). Older people with dementia may be treated unfairly in hospital since their ability to make decisions including those related to healthcare is diminished (Alzheimers Disease International 2019). As the condition advances, the older person with dementia may have difficulty explaining their symptoms and communicating their past medical history.

In the ED, rapid assessment to detect life-threatening conditions is emphasised (Parke et al. 2013; McConnell et al. 2016). During the course of a rapid assessment the ED nurse may fail to pick up on subtle signs of illness, misattributing physical symptoms to the dementia rather than an underlying serious condition (Shefer et al, 2014). Moreover, other important elements of care such as pain management, assistance with personal hygiene or pressure area care can become less of a priority (Dahlen et al. 2012). This may lead to a host of negative consequences for the older person with dementia, such as suboptimal pain management, worsening of behavioural symptoms and even delayed or inappropriate treatment. This disparity is 
unacceptable and adds to the distress of the older person with dementia and their carers (Burgstaller et al, 2018). Carers are defined as adults aged over 18 providing care for another adult who may be a family member, as distinct from paid or voluntary care (National Institute for Health and Care Excellence, 2020). Therefore, identifying research to inform nursing practice is essential in improving ED care experiences for this group.

\subsection{Background}

Three systematic reviews examined what clinical interventions were effective for older people with dementia or cognitive impairment in EDs and whether ED culture and context had an impact on their effectiveness (Parke et al, 2011; Clevenger et al, 2012; Schnitker et al, 2013). These three reviews included research that explored the use of screening tools (falls risk, delirium, pain assessment) and education of staff to enhance dementia care experiences (Parke et al, 2011; Clevenger et al, 2012; Schnitker et al, 2013). In all three reviews there was little evidence of the effectiveness of the tools and the educational interventions. The role of ED nurses in enhancing experiences was considered only as part of screening for delirium or cognitive impairment.

Overall, these reviews highlighted a lack of high-quality evidence to support ED practice development to enhance the care of persons living with dementia admitted to an ED. No studies reported what was important to older people with dementia and their carers in an ED visit (Parke et al, 2011). In addition, no studies examined ED culture and context and the possible impact of that on care processes such as nurse triage assessment and identification of acute illness in an older person with dementia (Clevenger et al, 2012). 
Recently, research has piloted the use of hospital readiness communication tools and the Pain Assessment in Advanced Dementia tool (PAINAD) to improve dementia care in ED (Fry et al, 2015a; 2015b; Parke et al, 2019). These tools show promise, but need further development before they are ready for practice. In improving services, those with the greatest insights about what needs to change or what can be improved are those receiving and giving care in frontline practice (Parke et al, 2011; Manley et al, 2011; Dewar and Cook, 2014). These three reviews recommend that the ED experiences of older people with dementia, their carers and nurses must be captured to determine what strategies might enhance care in this context and why. The role of carers and their involvement in more dementia-attuned ED care must also be further explored (Parke et al, 2011; Clevenger et al, 2012; Schnitker et al, 2013).

\subsection{Aims}

The aims of this integrative review were to build on the findings of the three previous systematic reviews and to identify the experiences of older people with dementia, their carers and ED nurses.

\subsection{Method}

An integrative review of primary research studies was conducted using a seven step (Table 1) systematic approach developed by Wakefield (2014):

- Generate a researchable question

- Select a database

- Clarify the terms to be used to access the literature

- Select the literature

- Search the literature 
- Analyse, synthesise and critique the articles

- $\quad$ Present the findings.

\subsection{Literature search}

From a modified PICo tool (Table 1) key search terms were generated to focus the review question (Aromataris and Munn, 2017). A search of the online databases Cumulative Index of Nursing and Allied Health Literature (CINAHL), Medline and PsychINFO was performed. Inclusion criteria comprised English language papers published in peer-reviewed journals from 1 January 2012 to 30 April 2019 in order to build on the three previous reviews.

\begin{tabular}{|l|l|}
\hline \multicolumn{3}{|c|}{ Table 1. PICo tool } \\
\hline Population (P) & Older people with dementia, carers, \\
& emergency department nurses \\
\hline Phenomenon of interest (I) & Dementia/experiences of giving and \\
& receiving care \\
\hline Context (CO) & Emergency department setting \\
\hline
\end{tabular}

Source: Briggs, 2011

\subsection{Eligibility criteria}

In keeping with Wakefield (2014), the review focused on primary research exploring the experiences of older people with dementia, their carers and ED nurses. Grey literature and discussion or opinion papers were excluded. 


\subsection{Search strategy}

Search terms were used in combination with the Boolean operators 'AND' and 'OR' to identify all relevant articles (Box 1). Different combinations of the search terms were used to widen the search.

Box 1. Example search: Medline

Search terms used

- Dementia OR Alzheimer's OR cognitive impairment

- Family members OR relatives OR carers OR caregivers

- Nurse OR nurses OR nursing

- Older adults OR older people OR elderly OR seniors OR geriatrics

- Emergency department OR emergency room OR accident \& emergency OR A\&E

- Experiences OR perceptions OR attitudes OR views OR feelings

\subsection{Study selection}

Articles were screened initially by title and abstract for relevance and then by reading the full text. As all articles included were qualitative, they were appraised using the Critical Appraisal Skills Programme (CASP) (2018) tool for qualitative research (Box 2). The CASP framework assesses the methodological quality and strength of research using a grading system of 10 questions resulting in a possible CASP score of 10. All papers were of good methodological quality. From each paper, relevant information including study design, country, method, sample characteristics, approach to data analysis and interpretation, impact on clinical practice 
and information relevant to review aims was extracted (Table 2). Identified articles were thematically analysed using the six-step approach described by Clarke and Braun (2013):

Box 2. Qualitative checklist for the appraisal of qualitative research

- Was there a clear statement of the aims of the research?

- Is a qualitative methodology appropriate?

- Was the research design appropriate to address the aims of the research?

- Was the recruitment strategy appropriate to the aims of the research?

- Was the data collected in a way that addressed the research issue?

- Has the relationship between researcher and participants being adequately considered?

- Have ethical issues been taken into consideration?

- Was the data analysis sufficiently rigorous?

- Is there a clear statement of findings?

- How valuable is the research?

- Familiarisation

- Coding

- Searching for themes

- Reviewing themes

- Defining and naming themes

- Writing up.

Each article was examined and the authors discussed core ideas, concepts and naming of themes. 


\begin{tabular}{|c|c|c|c|c|c|}
\hline Authos/year/country/title & Type of study & Research aims & $\begin{array}{l}\text { Data } \\
\text { collection/analysis }\end{array}$ & Key findings & Key message \\
\hline $\begin{array}{l}\text { Parke et al } 2013 \text { Canada } \\
\text { Facilitators and barriers to } \\
\text { safe emergency } \\
\text { department transitions } \\
\text { for community-dwelling } \\
\text { older people with } \\
\text { dementia and their } \\
\text { caregivers: a social } \\
\text { ecological study }\end{array}$ & $\begin{array}{l}\text { Interpretive, } \\
\text { qualitative exploratory } \\
\text { design } \\
\text { Purposive sampling } \\
\text { Participants were: PWD } \\
\text { plus family } \\
\text { member/carer (6) } \\
\text { Carers (4) ED nurses } \\
\text { (10) Nurse practitioners } \\
\text { (4) }\end{array}$ & $\begin{array}{l}\text { To identify factors that } \\
\text { impede/facilitate safe } \\
\text { transitional care for } \\
\text { PWD in the ED. To } \\
\text { identify potential } \\
\text { solutions that would } \\
\text { support nurses to } \\
\text { provide sensitive care }\end{array}$ & $\begin{array}{l}\text { Three phases: } \\
\text { interviews; creation of } \\
\text { a photographic } \\
\text { narrative journal; } \\
\text { photo-elicitation focus } \\
\text { groups. Verbatim } \\
\text { transcription. Nvivo } \\
\text { Constant comparative } \\
\text { analysis }\end{array}$ & $\begin{array}{l}\text { Being under-triaged; } \\
\text { time pressures; lack of } \\
\text { attention to basic } \\
\text { needs; feeling ignored, } \\
\text { forgotten and } \\
\text { unimportant. Triage } \\
\text { system in the ED does } \\
\text { not recognise atypical } \\
\text { presentations-sets in } \\
\text { motion a cascade of } \\
\text { vulnerability of older } \\
\text { PWD. Family members } \\
\text { value the relational } \\
\text { aspects of care- } \\
\text { recognition of } \\
\text { vulnerability, } \\
\text { communication, } \\
\text { interactions with } \\
\text { nurses }\end{array}$ & $\begin{array}{l}\text { Nurses should be } \\
\text { advocates for } \\
\text { relationship-centred } \\
\text { care } \\
\text { Nurses need support } \\
\text { to carry out best } \\
\text { practice } \\
\text { Difficult to recruit } \\
\text { older people with } \\
\text { dementia to the study } \\
\text { because of effects of } \\
\text { disease } \\
\text { Need for research } \\
\text { about context } \\
\text { Need for research that } \\
\text { focuses on what works } \\
\text { well and why }\end{array}$ \\
\hline $\begin{array}{l}\text { Fry et al 2015(a) Australia } \\
\text { Emergency nurses' } \\
\text { perceptions of the role of } \\
\text { confidence, self-efficacy } \\
\text { and reflexivity in } \\
\text { managing the cognitively } \\
\text { impaired older person in } \\
\text { pain }\end{array}$ & $\begin{array}{l}\text { Exploratory qualitative } \\
\text { study. Purposive } \\
\text { sampling } \\
\text { Part of a multicentre } \\
\text { study that reported } \\
\text { findings from } 16 \text { focus } \\
\text { groups across } 4 \text { EDs }\end{array}$ & $\begin{array}{l}\text { To explore practice of } \\
\text { care among ED nurses } \\
\text { caring for older people } \\
\text { with cognitive } \\
\text { impairment who } \\
\text { presented in pain from } \\
\text { a long bone fracture }\end{array}$ & $\begin{array}{l}\text { Focus groups (4) } \\
\text { Nvivo } 9.2 \\
\text { Thematic analysis }\end{array}$ & $\begin{array}{l}\mathrm{Cl} \text { is a barrier to pain } \\
\text { management and } \\
\text { often leads to } \\
\text { suboptimal care } \\
\text { because of lack of } \\
\text { verbal response. ED } \\
\text { nurses need high levels } \\
\text { of confidence and self- }\end{array}$ & $\begin{array}{l}\text { Being confident and } \\
\text { having self-efficacy can } \\
\text { help ED nurses to } \\
\text { develop a more } \\
\text { therapeutic } \\
\text { relationship with the } \\
\text { older person with Cl } \\
\text { and their family }\end{array}$ \\
\hline
\end{tabular}




\begin{tabular}{|c|c|c|c|c|c|}
\hline & $\begin{array}{l}\text { with } 80 \text { ED nurse } \\
\text { participants }\end{array}$ & & & $\begin{array}{l}\text { efficacy (ability to act) } \\
\text { to initiate and deliver } \\
\text { high-quality care for } \\
\text { this group }\end{array}$ & $\begin{array}{l}\text { members. Confidence } \\
\text { and self-efficacy is } \\
\text { central to caring and a } \\
\text { compassionate } \\
\text { approach. Need for } \\
\text { education and clinical } \\
\text { exposure to develop } \\
\text { confidence and self- } \\
\text { efficacy }\end{array}$ \\
\hline $\begin{array}{l}\text { Fry et al 2015(b) Australia } \\
\text { Title Emergency nurses' } \\
\text { perceptions of the role of } \\
\text { family/carers in caring for } \\
\text { cognitively impaired older } \\
\text { persons in pain: a } \\
\text { descriptive qualitative } \\
\text { study }\end{array}$ & $\begin{array}{l}\text { Qualitative descriptive } \\
\text { study } \\
\text { Purposive sampling } \\
\text { See above (Fry et al, } \\
\text { 2015a) }\end{array}$ & $\begin{array}{l}\text { To understand ED } \\
\text { nurses' perceptions of } \\
\text { the role of } \\
\text { family/carers for older } \\
\text { cognitively impaired } \\
\text { persons experiencing } \\
\text { pain as a result of a } \\
\text { long bone fracture }\end{array}$ & $\begin{array}{l}\text { Focus groups (4) } \\
\text { Nvivo } 9.2 \\
\text { Thematic analysis } \\
\text { (Gibbs, 2007) }\end{array}$ & $\begin{array}{l}\text { ED nurses perceive } \\
\text { that family members: } \\
\text { were valuable in } \\
\text { assisting staff to build } \\
\text { the clinical picture on } \\
\text { arrival in the ED; can } \\
\text { provide critical } \\
\text { information that } \\
\text { would otherwise be } \\
\text { unknown; reduce } \\
\text { negative impact of the } \\
\text { ED environment on } \\
\text { patient } \\
\text { If family members } \\
\text { were not present, this } \\
\text { added to the workload } \\
\text { of nurses who could } \\
\text { not deliver the care } \\
\text { the person with Cl } \\
\text { required } \\
\text { Worry and stress for } \\
\text { family members. ED } \\
\text { nurses expect family } \\
\text { members to provide }\end{array}$ & $\begin{array}{l}\text { Family members are } \\
\text { the hidden workforce. } \\
\text { Collaboration between } \\
\text { family members and } \\
\text { nurses needs further } \\
\text { exploration. Role of } \\
\text { family members in ED } \\
\text { is sometimes unclear } \\
\text { More research needed } \\
\text { to determine family } \\
\text { members' perceptions } \\
\text { of emergency care }\end{array}$ \\
\hline
\end{tabular}




\begin{tabular}{|c|c|c|c|c|c|}
\hline & & & & $\begin{array}{l}\text { personal care but not } \\
\text { all family members are } \\
\text { comfortable with this }\end{array}$ & \\
\hline $\begin{array}{l}\text { Hunter et al, } 2017 \text { Canada } \\
\text { Balancing safety and } \\
\text { harm for older adults with } \\
\text { dementia in rural } \\
\text { emergency departments: } \\
\text { health professionals' } \\
\text { perspectives }\end{array}$ & $\begin{array}{l}\text { Interpretative, } \\
\text { descriptive exploratory } \\
\text { design: social ecological } \\
\text { perspective } \\
\text { Purposive/snowballing } \\
\text { sampling }\end{array}$ & $\begin{array}{l}\text { To understand safety } \\
\text { and harm in rural ED } \\
\text { transitional care for } \\
\text { community-dwelling } \\
\text { older adults with } \\
\text { dementia from } \\
\text { perspectives of HPs. } \\
\text { HPs asked to describe } \\
\text { their experiences of } \\
\text { working with older } \\
\text { people with dementia } \\
\text { and their caregivers in } \\
\text { ED }\end{array}$ & $\begin{array}{l}2 \text { small rural EDs (95 } \\
\text { inpatient beds/76 } \\
\text { inpatient beds) } \\
12 \text { health } \\
\text { professionals: nurses, } \\
\text { social worker, } \\
\text { occupational therapist, } \\
\text { physiotherapist, } \\
\text { medics } \\
\text { Semi-structured } \\
\text { interviews }\end{array}$ & $\begin{array}{l}\text { HP perspectives: ED is } \\
\text { challenging for older } \\
\text { people with dementia. } \\
\text { Chaotic and } \\
\text { overcrowded. This } \\
\text { group not a priority } \\
\text { due to priorities of } \\
\text { emergency care. HP } \\
\text { sometimes too busy to } \\
\text { give proper care to this } \\
\text { group. Competing } \\
\text { pressures in triage. } \\
\text { HPs experience moral } \\
\text { distress when they } \\
\text { cannot provide care } \\
\text { that they should be } \\
\text { able to give. Negative } \\
\text { consequences: no safe } \\
\text { space, no quiet } \\
\text { environment. HPs } \\
\text { sensitive to family } \\
\text { member situation. } \\
\text { Need to look at older } \\
\text { people with dementia } \\
\text { and family member as } \\
\text { a complete package- } \\
\text { obligations to both }\end{array}$ & $\begin{array}{l}\text { Small ED can be of } \\
\text { benefit: potential to } \\
\text { get older person with } \\
\text { dementia out of ED } \\
\text { faster due to good } \\
\text { community links. } \\
\text { Disadvantages: making } \\
\text { assumptions or } \\
\text { becoming complacent } \\
\text { about patients who } \\
\text { are well known to HPs } \\
\text { Making things better: } \\
\text { more resources, } \\
\text { valuing contribution of } \\
\text { family members who } \\
\text { could provide care in } \\
\text { ED. Changing triage } \\
\text { approach to older } \\
\text { people with dementia, } \\
\text { getting to know the } \\
\text { person beyond the } \\
\text { superficial, better } \\
\text { discharge planning }\end{array}$ \\
\hline $\begin{array}{l}\text { Watkins et al, } 2019 \\
\text { Ireland }\end{array}$ & $\begin{array}{l}\text { Appreciative inquiry: } \\
\text { discovery phase }\end{array}$ & $\begin{array}{l}\text { To generate insights } \\
\text { about what matters } \\
\text { and is valued by family }\end{array}$ & $\begin{array}{l}\text { Single site, large ED } \\
\text { Phase 1: data analysis } \\
\text { Family members (15) }\end{array}$ & $\begin{array}{l}\text { ED } \\
\text { Phase 1: data analysis } \\
\text { Family members (15) }\end{array}$ & $\begin{array}{l}\text { Older people with } \\
\text { dementia did not take }\end{array}$ \\
\hline
\end{tabular}




\begin{tabular}{|c|c|c|c|c|}
\hline $\begin{array}{l}\text { Caring for an older person } \\
\text { with dementia in the } \\
\text { emergency department } \\
\text { (ED): An appreciative } \\
\text { inquiry exploring family } \\
\text { member and ED nurse } \\
\text { experiences }\end{array}$ & $\begin{array}{l}\text { members of older } \\
\text { people with dementia } \\
\text { in the ED and to } \\
\text { capture the } \\
\text { experiences of ED } \\
\text { nurses looking after } \\
\text { older people with } \\
\text { dementia in an } \\
\text { episode of care }\end{array}$ & $\begin{array}{l}\text { ED nurses (12) } \\
\text { Participant observation } \\
\text { (30 hours) } \\
\text { Semi-structured } \\
\text { interviews } \\
\text { Thematic analysis }\end{array}$ & $\begin{array}{l}\text { ED nurses (12) } \\
\text { Participant } \\
\text { observation ( } 30 \text { hours) } \\
\text { Semi-structured } \\
\text { interviews } \\
\text { Thematic analysis } \\
\quad \text { Two themes: } \\
\text { what matters to family } \\
\text { members; challenges } \\
\text { for family members } \\
\text { and nurses in ED. Being } \\
\text { triaged quickly } \\
\text { enhances experiences. } \\
\text { Triage nurse under } \\
\text { pressure to see } \\
\text { everybody as fast as } \\
\text { possible. Priority has } \\
\text { to be given to heart } \\
\text { attacks/strokes. } \\
\text { Cubicle space offers } \\
\text { sanctuary. Family } \\
\text { members fear way } \\
\text { older person with } \\
\text { dementia might } \\
\text { behave in a chaotic } \\
\text { environment. Risk of } \\
\text { becoming a public } \\
\text { spectacle. 'Conveyor } \\
\text { belt' nursing. ED } \\
\text { nurses remote from } \\
\text { personal contact. } \\
\text { Some ED nurses } \\
\text { managing to integrate }\end{array}$ & $\begin{array}{l}\text { part as in advanced } \\
\text { state of the disease } \\
\text { Modification of triage } \\
\text { system required to } \\
\text { prioritise older people } \\
\text { with dementia. } \\
\text { Increased education } \\
\text { for nurses about the } \\
\text { need for family } \\
\text { member insights. ED } \\
\text { nurses need to find a } \\
\text { way to blend technical } \\
\text { and relational aspects } \\
\text { of care. Some ED } \\
\text { nurses doing this. } \\
\text { Need to find a way to } \\
\text { make this happen } \\
\text { more frequently }\end{array}$ \\
\hline
\end{tabular}




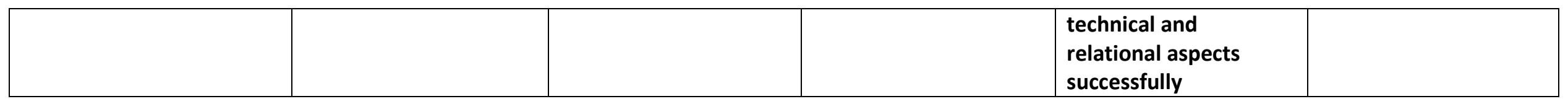

$\mathrm{Cl}=$ cognitive impairment; $\mathrm{ED}=$ =emergency department; Nvivo=data analysis software $\mathrm{PWD=person}$ with dementia; Key: $\mathrm{HP=health}$ professional; ED=emergency department 


\subsection{Results}

\subsection{Summary of characteristics}

Initially 470 papers were retrieved. After screening titles and abstracts for relevance and removing duplicates, five papers from four studies were synthesised in the review (Figure 1). All used interpretative, qualitative designs (Table 2). Countries of origin were Canadian $(n=2)$, Australian ( $n=1)$ and Ireland ( $n=1)$. Two articles were from a single study (Fry et al. 2015a, b). These two papers were part of a large multicentre study that conducted focus groups $(n=16)$ with ED nurses ( $n=80$ ) across four EDs. Only one study (Parke et al. 2013) included older people with dementia $(n=6)$.

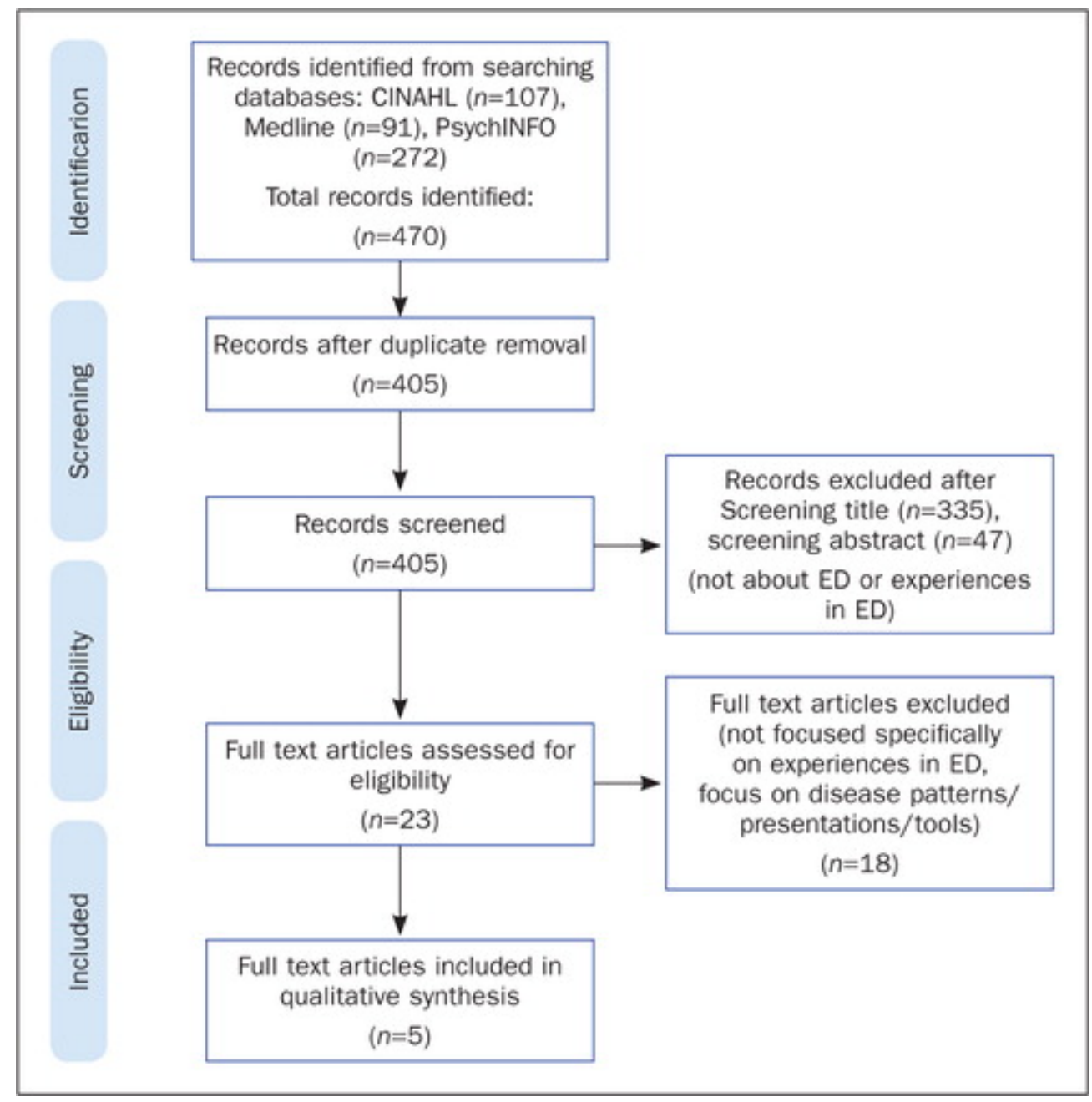

Figure 1. PRISMA flow diagram showing the search strategy 
After analysis, three main themes emerged. These were as follows:

- Carers and older people with dementia waiting and worrying

- Nurses juggling priorities

- Strategies for improvement; taking a partnership approach

\subsection{Carers and older people with dementia waiting and worrying}

A visit to the ED was a stressful experience for carers primarily because they worried about how the older person with dementia might react in a chaotic environment (Parke et al, 2013; Fry et al, 2015a; Watkins et al, 2019). Carers found that waiting to be triaged was challenging. Triage affords priority to those patients who present with an urgent problem such as a heart attack or stroke (Parke et al, 2013; Hunter et al, 2017; Watkins et al, 2019). Under this triage system, if the older person with dementia does not meet this urgent category or if they cannot explain their symptoms because of severe cognitive impairment, they are likely to be given a lower triage category by the triage nurse (Parke et al, 2013; Fry et al, 2015a; 2015b; Hunter et al, 2017; Watkins et al, 2019). The older person with dementia may slip down the priority level because they have dementia. This could result in delayed treatment and their needs being underestimated and unmet. Carers were left feeling that other vital aspects of care, such as effective pain relief, nutrition, hydration or personal hygiene needs were not afforded attention.

Carers also believed that a delay in triage could potentially compromise the dignity of the older person with dementia and their behaviour might deteriorate (Parke et al, 2013; Watkins et al, 2019). Behavioural symptoms such as swearing or shouting drew attention from onlookers and 
other patients waiting to be seen (Watkins et al, 2019). For this reason, carers wanted the older person with dementia to be given priority to protect them from becoming a 'spectacle' (Watkins et al, 2019). From a patient perspective Parke et al (2013) suggested that older people affected by dementia experienced panic in a crowded ED waiting room. Older people with dementia were worried about the physical problem that brought them to ED, but also worried about not being able to cope with high anxiety levels in an environment that was very stressful for them. Nurses in a busy ED did not always appreciate such anxieties and stress.

\subsection{Nurses juggling priorities}

In all four studies, the nurses acknowledged that caring for an older person with dementia in an ED was challenging (Parke et al, 2013; Fry et al, 2015a, 2015b; Hunter et al, 2017; Watkins et al, 2019). The ED nurses highlighted the complexity of caring for patients with diverse needs. This included the older person with dementia who may require additional care such as management of behavioural symptoms, which can be exacerbated by acute illness. The ED nurses described a work environment that was chaotic and congested. They described the pressures of juggling time, space and high numbers of patients with diverse presentations (Parke et al, 2013; Hunter et al, 2017; Watkins et al, 2019). ED nurses thought that the priorities of emergency care were unsympathetic to the more relational elements of care such as relieving anxiety or offering reassurance to the older person with dementia or their carer (Parke et al, 2013; Fry et al, 2015a, 2015b; Hunter et al, 2017; Watkins et al, 2019).

There were times when ED nurses were able to provide a more personal approach, whether this was finding out what pain relief worked for an individual or moving a person to a cubicle space to protect the older person with dementia from the public gaze (Fry et al, 2015a; Watkins 
et al, 2019). ED nurses stated that they experienced emotional distress when heavy workloads impacted their ability to give the older person with dementia the type of care they needed and deserved (Fry et al, 2015b; Hunter et al, 2017).

\subsection{Strategies for improvement; taking a partnership approach}

The studies in this review highlighted some more negative aspects of the care of the older person with dementia in ED, but also identified potential strategies for improvement. Three studies recommended modifications to the current triage system so that the needs of the older person with dementia could be assessed in a timely manner (Parke et al, 2013; Hunter et al, 2017; Watkins et al, 2019).

Involving carers as part of relationship-centred approaches was another strategy. Relationshipcentred care calls for a shift in focus from medical interventions to human connections and relationships as equally important elements in the nursing process (Parke et al, 2013; Watkins et al, 2019). The ED nurses believed that the presence of the carer may calm an older person with dementia who is distressed in a chaotic environment (Parke et al, 2013; Fry et al, 2015a; 2015b). Carers could help with personal care (Hunter et al, 2017) and their knowledge about the older person with dementia as a person could assist ED nurses to get a better sense of care needs (Parke et al, 2013; Fry et al, 2015a; 2015; Hunter et al, 2017; Watkins et al, 2019). The ED nurses stated that carer presence could also reduce their workload and stress (Fry et al, 2015b). All articles suggested, therefore, that a practice partnership between carer and ED nurse could be fostered within a relationship-centred approach to care (Parke et al, 2013; Fry et al, 2015a; 2015b; Hunter et al, 2017; Watkins et al, 2019). The role of carers in partnership with ED nurses appears promising (Fry et al, 2015b; Hunter et al, 2017). 


\subsection{Discussion}

The studies in this review provide a snapshot of the experiences of carers accompanying an older person with dementia in ED and the competing demands on nurses caring for them (Parke et al. 2013; Fry et al. 2015a, b; Hunter et al. 2017; Watkins et al. 2019). Few studies were identified by the literature search, suggesting that research in this field is underdeveloped. Three previous systematic reviews recommended more research of the experiences of older people with dementia, their carers and ED nurses to determine what strategies might enhance care and why (Parke et al. 2011; Clevenger et al. 2012; Schnitker et al. 2013). They recognised that the role of carers in ED should be further explored. However, the research evidence to support improvement in ED dementia care has progressed little in the past seven years. This review suggests that older people with dementia slip down the priority level in ED simply because they have dementia. ED nurses may misattribute exacerbation of behavioural symptoms to cognitive impairment and so the potential for the older person with dementia to have a serious underlying condition is overlooked. This is known as 'diagnostic overshadowing' (Shefer et al, 2014). Such discrimination is unacceptable and results in the older person with dementia receiving delayed or inadequate care. It is difficult to say if this is common practice. Increasing awareness among ED nurses of the positive contribution that carers can make to the assessment process could be part of the solution in preventing this.

Practice partnerships between carers and ED nurses is proposed as a strategy to address the needs of older people with dementia in a relationship-centred way. Older people with dementia in ED may be in the advanced stages of the condition (Sleeman et al, 2018) and therefore unable to tell healthcare staff how they feel or what is happening. The practice 
partnership centralises the needs of the older person with dementia when they are unable to do this for themselves. Relationship-centred care focuses on three components:

- Nurse-patient-carer interactions

- Physical aspects of care (personal hygiene, pain control, eating and drinking)

- The context in which care is delivered (Kitson et al, 2013; Feo et al, 2018; Uhrenfeldt et al, 2018).

It is suggested that nursing aspires to more relationship-centred care (Sharp et al, 2017) and adopting such an approach could have several benefits in an ED context. Older people with dementia may receive care that is sensitive to their needs, promoting their dignity. Carer anxiety will be reduced and the self-worth and sense of purpose of nurses will be increased (Ryan et al, 2008; Dewar and Nolan, 2013; Coffey et al, 2019). Frameworks such the Fundamentals of Care Framework (Kitson et al, 2013) or the Senses Framework (Nolan et al, 2006) may support this in practice. The Senses framework (Nolan et al, 2006) comprises six 'senses', of:

- Security

- Belonging

- Continuity

- Purpose

- Achievement

- Significance. 
The underlying premise is that good relationships and good care can be delivered only when the 'senses' are experienced by all groups involved in the episode of caring (Ryan et al, 2008). However, there remains a tension in providing technically orientated care and relationship centred care (Dewing and Dijk 2016; Brooke and Ojo 2017, Sharp et al. 2018) and perhaps this tension is most apparent in ED where life-saving interventions must take priority (Mollaoğlu and Çelik 2016). The triage nurse, for example, is under pressure to ensure that those patients who present with a heart attack or stroke receive treatment in the fastest time possible (Parke et al. 2013; Watkins et al. 2019). The ED nurse operates within this system, in the knowledge that it may afford the older person with dementia lesser priority with potentially negative consequences (Parke et al. 2011; Clevenger et al. 2012, Coffey et al. 2014).

Nurses in ED are expected to perform in a highly efficient task orientated way, yet have to blend this with relationship orientated care when the situation demands it (Dewar and Nolan 2013). As it stands, there is little consensus on how this may be achieved or indeed whether or not this is possible in the current organisational climate. The ED has been described as a warzone (McConnell et al. 2016) and may not be the right place to care for the older person with dementia. It is questionable whether relationship centred care is even possible in such a setting (DeVries et al. 2016; Dewing and Dijk 2016). Meanwhile older people with dementia continue to require the services of ED in increasing numbers and there is little in the way of alternative pathways.

This review has highlighted the potential of practice partnerships between ED nurses and carers of older people with dementia as a strategy to move towards relationship centred care. However, there are challenges though in implementing this in practice. In systematic reviews of dementia care in acute hospital settings other than ED (acute surgical ward, acute medical 
wards), education is seen as important to bridge the gap between the rhetoric of relationshipcentred care and practice (Godfrey et al. 2018). It is recommended that education strategies should reflect on practice and be context based (Digby et al. 2017; Turner et al. 2017; Dewing and Dijk 2016). Mandatory education programmes may also be helpful (Houghton et al. 2016; Surr and Gates 2017). However, group-based learning away from the clinical area and incorporating personal stories of carers appears to be more beneficial (Surr and Gates 2018). Education should focus on the human dimensions of care to include the experiences and wellbeing of nurses (Coffey et al. 2019). In addition, there is a need for organisations to support nurses in blending technical and relationship centred care approaches. This support is long awaited in a hospital culture that appears to have de-valued human perspectives and relational practices (Dewing and Dijk 2016; Digby et al. 2016).

\subsection{Conclusion}

This review aimed to identify the experiences of older people with dementia and their carers of being in an ED and ED nurses' experiences of caring for them. Admission to an ED is stressful for the older person with dementia whose needs may not be met and for the carers accompanying them. In the articles examined, the ED setting also presented challenges for ED nurses who felt they were not always able to give optimal care to these patients. Those experiences were shaped by the impact of this environment on nurses' capacity to meet the needs of older people with dementia. The studies in this review advocated for relationshipcentred approaches to enhance the experience of older people with dementia and their carers in ED. However, more evidence on how this might be negotiated in clinical practice is needed. There is potential, however, in developing practice partnerships between ED nurses and carers 
as a component of relationship-centred care. Enhancing the ED experiences of older people with dementia will require collective effort to support ED nurses to blend the technical and relational aspects of care. This effort must include organisational support but also practice development strategies that engage ED nurses in shaping how things are done. A strength of this review is that it has identified a dearth of evidence. There is a need for participatory research approaches to determine what matters and is valued by older people with dementia and their carers in the ED. Collaborative and creative research methods may offer an opportunity for older people with dementia to become part of the research process.

\section{Limitations}

This review focus was solely on primary research, however few research papers were identified. Despite this, this review builds on the three existing reviews that conducted a qualitative and quantitative synthesis of over 60 papers from 1980 to 2012 . The authors acknowledge publication bias. Grey literature and other potential empirical sources not in peer review publications may have identified unpublished articles relevant to this review. Secondary interpretation of author findings is also a potential limitation.

\section{References}

Alzheimers Disease International. (2019).

World Alzheimers Report 2019: Attitudes to dementia.

Alzheimers Disease International: London.

https://www.alz.co.uk/research/world-report-2019

Briggs, J. (2014). Joanna Briggs Institute Reviewers' Manual: 2014 edition [Internet]. South Australia (Australia): The University of Adelaide.

Brooke, J. \& Ojo, O. (2017).

Elements of a sustainable, competent, and empathetic workforce to support patients with dementia during an acute hospital stay: A comprehensive literature review. International Journal of Health Planning Management, e10-e25. doi:10.1002/hpm.2448

Burgstaller, M., Mayer, H., Schiess, C., \& Saxer, S. (2018). Experiences and needs of relatives of people with dementia in acute hospitals -A meta-synthesis of qualitative studies. Journal of Clinical Nursing, 27(3-4), 502-515. doi:10.1111/jocn.13934 
Clarke, V. \& Braun, V. (2013).

Teaching thematic analysis: Overcoming challenges and developing strategies for effective learning. The Psychologist, 26(2), 120-123.

Retrieved from http://eprints.uwe.ac.uk/21155

Clevenger, C. K., Chu, T. A., Yang, Z., \& Hepburn, K. W. (2012). Clinical care of persons with dementia in the emergency department: a review of the literature and agenda for research. Journal of the American Geriatrics Society, 60(9), 1742-1748. doi:10.1111/j.1532-5415.2012.04108.x

Coffey, A., Saab, M. M., Landers, M., Cornally, N., Hegarty, J., Drennan, J., . . Savage, E. (2019). The Impact of Compassionate Care Education on Nurses: A Mixed-Method Systematic Review. Journal Of Advanced Nursing.

Coffey, A., Tyrrell, M., Buckley, M., Manning, E., Browne, V., Barrett, A., \& Timmons, S. (2014). A multicentre survey of acute hospital nursing staff training in dementia care. J Clin Nurs, 2(4), 39.

Dahlen, I, Lars W, \& Annsofie Adolfsson. (2012). Experience of being a low priority patient during waiting time at an emergency department. Psychology research and behavior management 5 (2012): 1. doi: 10.2147/PRBM.S27790

de Vries, K., Drury-Ruddlesden, J., \& Gaul, C. (2016). 'And so I took up residence': The experiences of family members of people with dementia during admission to an acute hospital unit. Dementia, 18(1), 36-54.

Dewar, B., \& Cook, F. (2014). Developing compassion through a relationship centred appreciative leadership programme. Nurse Education Today, 34(9), 1258-1264.

Dewar, B., \& Nolan, M. (2013). Caring about caring: developing a model to implement compassionate relationship centred care in an older people care setting. International Journal Of Nursing Studies, 50(9), 1247-1258.

Dewing, J., \& Dijk, S. (2016). What is the current state of care for older people with dementia in general hospitals? A literature review. Dementia, 15(1), 106-124.

Digby, R., Lee, S., \& Williams, A. (2017). The experience of people with dementia and nurses in hospital: an integrative review. Journal Of Clinical Nursing, 26(9-10), 1152-1171.

Digby, R., Lee, S., \& Williams, A. (2018). The liminality of the patient with dementia in hospital. Journal of Clinical Nursing, 27(1-2), e70-e79.

Godfrey, M., Young, J., Shannon, R., Skingley, A., Woolley, R., Arrojo, F., .. . Surr, C. (2018). The Person, Interactions and Environment Programme to improve care of people with dementia in hospital: a multisite study. Health Services and Delivery Research, 6(23).

Houghton, C., Murphy, K., Brooker, D., \& Casey, D. (2016). Healthcare staffs' experiences and perceptions of caring for people with dementia in the acute setting: Qualitative evidence synthesis. International Journal Of Nursing Studies, 61, 104-116.

Kitson, A., Conroy, T., Kuluski, K., Locock, L., \& Lyons, R. (2013). Reclaiming and redefining the Fundamentals of Care: Nursing's response to meeting patients' basic human needs.

Manley, K., Sanders, K., Cardiff, S., \& Webster, J. (2011). Effective workplace culture: the attributes, enabling factors and consequences of a new concept. International Practice Development Journal, 1(2), 1-29.

McConnell, D., McCance, T., \& Melby, V. (2016). Exploring person-centredness in emergency departments: A literature review. International emergency nursing, 26, 38-46.

Mollaoğlu, M., \& Çelik, P. (2016). Evaluation of emergency department nursing services and patient satisfaction of services. Journal Of Clinical Nursing, 25(19-20), 2778-2785.

National Institute for Health and Care Excellence. (2017). Guideline Scope Carers: Provision of support for adult carers. Retrieved from http://www.nice.org.uk/guidance/gidng10046/documents/draft-scope. 
Nolan, M., Brown, J., Davies, S., Nolan, J., \& Keady, J. (2006). The Senses Framework: improving care for older people through a relationship-centred approach. Getting Research into Practice (GRiP) Report No 2.

Parke, B., Beaith, A., Slater, L., \& Clarke, A. M. (2011). Contextual factors influencing success or failure of emergency department interventions for cognitively impaired older people: a scoping and integrative review. Journal Of Advanced Nursing, 67(7), 1426-1448. doi:10.1111/j.1365-2648.2011.05611.x

Parke, B., Hunter, K.F., Strain, L.A., Marck, P.B., Waugh, E.H. \& McClelland, A.J. (2013). Facilitators and barriers to safe emergency department transitions for community dwelling older people with dementia and their carers: A social ecological study. International Journal of Nursing Studies, 50, 1206-1218. doi:10.1016/ijnurstu.11.005

Parke, B., Hunter, K.F., Schulz, M.E. \& Jouanne, L. (2016). Know me - A new person - centred approach for dementia friendly emergency department care. Dementia, 1-16. doi:10.1177/1471301216675670

Pinkert, C., Faul, E., Saxer, S., Burgstaller, M., Kamleitner, D. \& Mayer, H. (2018). Experiences of nurses with the care of patients with dementia in acute hospitals: A secondary analysis. Journal of Clinical Nursing, 27(1-2), 162-172.

Ryan, T., Nolan, M., Reid, D., \& Enderby, P. (2008). Using the senses framework to achieve relationship-centred dementia care services: a case example. Dementia, 7(1), 71-93.

Schnitker, L., Martin-Khan, M., Beattie, E., \& Gray, L. (2013). What is the evidence to guide best practice for the management of older people with cognitive impairment presenting to emergency departments? A systematic review. Advanced Emergency Nursing Journal, 35(2), 154-169. doi:10.1097/TME.0b013e31828c7f4a

Sharp, S., Mcallister, M., \& Broadbent, M. (2018). The tension between person centred and task focused care in an acute surgical setting: A critical ethnography. Collegian, 25(1), 11-17.

Surr, C. A., \& Gates, C. (2017). What works in delivering dementia education or training to hospital staff? A critical synthesis of the evidence. International Journal Of Nursing Studies, 75, 172 188.

Turner, A., Eccles, F. J., Elvish, R., Simpson, J., \& Keady, J. (2017). The experience of caring for patients with dementia within a general hospital setting: a meta-synthesis of the qualitative literature. Aging \& Mental Health, 21(1), 66-76.

Uhrenfeldt, L., Sørensen, E. E., Bahnsen, I. B., \& Pedersen, P. U. (2018). The centrality of the nursepatient relationship: A Scandinavian perspective. Journal of Clinical Nursing.

Wakefield, A. (2014). Searching and critiquing the research literature. Nursing Standard (2014+), 28(39), 49.

Watkins, S.A., Murphy, F., Kennedy, C., Dewar, B., \& Graham, M. (2019). Caring for anolder person with dementia in the Emergency Department (ED): An appreciative inquiry exploring family member and ED nurse experiences. Journal of Clinical Nursing 28(7-8), 1346-1353.

Wortmann, M. (2012). Dementia: a global health priority-highlights from an ADI and World Health Organization report. Alzheimer's research \& therapy, 4(5), 40. 